\title{
A Research on Colours and Fastness Values of Different Materials Dyed with Some Natural Dyes
}

\author{
Selma Dolanbay Doğan ${ }^{1,}$, Meral Akan² \\ ${ }^{1}$ Department of Textile Design and Production, Faculty of Art and Design, Selçuk University, Konya, Turkey \\ ${ }^{2}$ Department of Traditional Turkish Arts, Faculty of Fine Arts, Selcuk University, Konya, Turkey
}

Email address:

selmadogan@selcuk.edu.tr(S.D.Dogan),makan@selcuk.edu.tr(M.Akan)

${ }^{*}$ Corresponding author

\section{To cite this article:}

Selma Dolanbay Doğan, Meral Akan. A Research on Colours and Fastness Values of Different Materials Dyed with Some Natural Dyes. International Journal of Materials Science and Applications. Vol. 7, No. 3, 2018, pp. 69-74. doi: 10.11648/j.ijmsa.20180703.11

Received: February 12, 2018; Accepted: March 13, 2018; Published: April 4, 2018

\begin{abstract}
Nowadays use of natural materials and natural methods is considered to be an element that increases the value of a product and contributes to sustainable life in environmental, economic and sociologic senses. Natural dyeing has been an avocation performed in the Anatolia region for centuries and can be used for dyeing of different materials. In this study, it is aimed to expose color values, color named, light and rubbing fastness of the colors that were obtained as a result of dyeing three different materials (wool yarn, cotton fabric and paper) with some natural dyes according to traditional method. In line with this aim, the materials were dyed with madder (Rubia tinctorium L.), walnut (Juglans regia L.), weld (Reseda luteola) and indigo. In consequence of the research; color names, color values, light and rubbing fastness of fifteen samples were determined. The result of the research were evaluated statistically using SPSS programme.
\end{abstract}

Keywords: Wool Yarn, Cotton Knitted Fabric, Paper*, Naturel Dyeing

\section{Introduction}

Colors are one of the indispensable and important elements of art in many areas [1] like textile, ancient writing, ornamentation etc. Natural dyeing is a coloring method to obtain dyestuffs from plants or animals and to dye different materials. One of the significant factors is that color fastnesses can be reached by determining color fastnesses suitable for usage area of the materials. Also it is a tradition that has been used for centuries in Anatolia for colorization of wool fiber. Every region in Anatolia has a rich cultural accumulation and its geographical structure and climatic conditions are thus suitable for growing a wide variety of plants, which ensured that the range of colors obtained in the field of natural dyeing is wide. This variety is commonly seen as shades of red, yellow and brown. Anatolian plant flora is effective in reaching these colors. In the study; madder (Rubia tinctorium L.), weld (Reseda luteola L.) and walnut (Juglans regia L.) plants were used to obtain red, yellow and brown respectively that are known as the main colors in natural dyeing as well as indigo for blue, and weld-indigo for green.
When various studies are carried out by using different mordant with madder (Rubia tinctorium L.), the degree of fastness is quite high, and various colors such as light red to dark red, dark orange, light tile, taba color and brown are obtained [2]. Various dyeing methods have been applied with madder up to day and Turkish red (Edirne Red), which has made a reputation in the world, has appeared. From the middle ages to the discovery of synthetic alizarin, this plant is known as the most important dyestuff, and agriculture and trade are intensely conducted. Alum (aluminum sulphate) gives the famous Turkish red color. Sources refer to the preservation of the mystery by the eastern people throughout history [3]. In historical sources, it is stated that the colors used in the clothes of the important people in ceremonial clothes are red.

Walnut (Juglans regia L.) plant belongs to the Juglans kind of Juglanddaceae family from Juglandales type [4]. It is a 10-25 $\mathrm{m}$ tall tree with a fairly broad crown and loose branches. Green crust and the leaves of walnut fruit have a substance named tannin along with volatile oil and juglone. Both the leaves and crusts are commonly used coloring agents in Turkey [5]. Among those, fruit crusts have the most fastness degree and widest usage [6]. Throughout history, many 
civilizations recognized walnut plants and used them as dyes. It was called "jovis" or "juglon" by the Romans. The ancient Greeks knew this substance, too. The coloring feature of the fibers in dyeing makes it possible for all countries to recognize and trade walnut fruit [3]. Anatolian walnut (Juglans regia), which has a great natural spreading area in the world as a result of its origins, has been seen outside of the natural spreading area through various migrations and commercial caravans, and in addition to tropical regions, it is a fruit which is grown almost everywhere in the world today [7]. It has been known for centuries in a very large area on the world that via the dyestuffs contained in walnut leaves brown tones are obtained. It is also used as an auxiliary dye to obtain black color on fabrics [8]. Dark brown can also be obtained from a dyeing made with walnut [9-11].

Weld (Reseda luteola) is a perennial plant that can grow in Anatolia up to a height of $1.5 \mathrm{~m}$. The plant grows at 400-1500 $m$ altitudes, in stony areas, in the high sections around Eastern Anatolia and Central Anatolian Salt Lake in Turkey. The portion of the plant that is above the ground is used in dyeing. However, the blooming upper branches contain more dyestuffs. The dyestuff it contains is luteolin. The flowers contain luteolin together with a small amount of apigenin. It is one of the sources of yellow coloring in dyeing. The use of Reseda luteola in Anatolia dates back to the 16th century. For instance, Uşak carpets and the carpets in TIEM were determined to have been dyed with weld in consequence of chemical analyses conducted on the carpets. The light fastness of weld is the highest among the plants. Weld has been used in dyeing for a long time and they have been planted in Europe [12].

As it is well known, indigo is a dyestuff obtained by using different methods from some plants, especially isatis tinctoria. It is considered the source of blue in implementations in which natural dyeing is practiced.

The demand for all natural methods and materials has increased and the "natural" has begun to reappear in order for a sustainable life to be achieved with the increase of customer consciousness, the adverse effect of chemical substances on the environment and human health. The use of natural materials and methods contributes to environmental, economic and social sustainability and is an increasingly important issue, and the fact that natural processes are followed in the production process of a product ensures that it can be preferred among similar products. In recent years, with the increase in the demand for products colored with natural dyes, the number of studies regarding natural dyes has started to increase. As a result of the literature research, it has been observed that the scope of the researches is limited by trying different natural dyes on a single material. For example; Giacomini et al. (2017) studied on silk fabric dyed with extract of yerba mate [13], Li et. al. (2016) studied on cotton and wool fabric dyed with persimmon dye [14], Nateri et. al. (2014) studied on nylon fabric dyed with weld and pomegranate peel as naturel dyes [15]. The practice of natural dyes on different materials is the subject of this research. This study is different from the literature as it is important to make natural dyeing experiments on different materials. In this research, it is aimed to dye three different materials such as wool yarn, cotton fabric and paper with natural dyes such as madder (Rubia tinctorium L.), weld (Reseda luteola L.), walnut (Juglans regia $L$.), indigo and to put forward color names, color values, light and rubbing fastnesses of colors obtained as a result of dyeing in a comparative manner.

\section{Material and Method}

\subsection{Material}

The material of the research consists of madder (Rubia tinctorium L.), walnut (Juglans regia L.), weld (Reseda luteola), indigo, wool yarn, cotton knitted fabric and paper. The technical specifications of these materials are listed below.

Wool yarn: nr. 2, 5, woolen carpet yarn

Cotton Fabric: $100 \%$ cotton, raw knitted fabric, interlock knit type, $260 \mathrm{gr} / \mathrm{m}^{2}$

Paper: White colored raw dough paper, $120 \mathrm{gr} / \mathrm{m}^{2}$

\subsection{Method}

\subsubsection{Dyeing Method}

Three different materials such as woolen yarn, cotton fabric and paper were dyed with traditional methods using madder, walnut, weld, indigo, and weld-indigo plants in order to see the effect of the same dyes on different materials. A total of fifteen dyeing were practiced and various colors were obtained. The dyeing of the paper differs from the dyeing of the yarn and fabric in the dyeing methods. In the same way, the dyeing made with indigo are different from the ones made with the plants. These processes will be explained in detail below.

In the dyeing of yarn, fabric and paper with madder, walnut and weld; 1:1 plant ratio was used according to the materials to be dyed and the dyeing were performed without mordant. The prepared plants were soaked in water for 10 minutes in order to allow water to pass through the dye contained in the parts used for dyeing. The plants were boiled for 1 hour according to the method of preparing hot extracts in water at a rate of $1 / 50$ according to the material to be dyed and the plant residues were removed by filtration at the end and the extract was obtained. The yarn and fabric samples prepared as 8 grams were boiled in the prepared extract for 60 minutes. Mineral water was added during boiling in preparing extract and dyeing the samples. After finishing dyeing of yarns and fabrics, samples were washed in cold water until color flow was completed. After the excess water of the samples was taken out, it was hanged and dried in shadow and airy environment. The paper samples prepared as 8 grams were stored in the hot extract for 60 minutes and then left to dry.

Indigo dyeings: 1:50 water, 1: 1 indigo, $1 \mathrm{~g}$ hydrosulfite and $0.5 \mathrm{cc} / \mathrm{lt}$ caustic were used for indigo colorings. The samples were added to the dyeing solution at $60^{\circ} \mathrm{C}$ for 10 minutes and the materials were removed from the solution and contacted 
with air to obtain colors.

Weld-indigo dyeings: The samples were first dyed with weld and then repeatedly with indigo for weld-indigo dyeing and obtained green colour.

\subsubsection{Identification and Naming of Obtained Colours}

The dyed samples were placed on a black background in a smooth form to receive natural daylight and were grouped by color differences and given a color name by a commission of three. Subjective evaluations have been made and named based on the colors and tones that can be seen in nature and previous work $[2,3]$.

\subsubsection{Evaluation of Colors Obtained with Colorimeter}

The colors of the dyed samples were evaluated objectively using a colorimeter (Tristimulus Colorimeter Sodexim 1866). The samples were measured for L (brightness co-ordinate), a (red-green co-ordinate), and $\mathrm{b}$ (blue-yellow co-ordinate) values to achieve $\mathrm{dE}$ (color difference) values.

Measurements made from the five different regions of the dyed samples were taken as the mean of the resulting data. During the measurement, the undyed materials were accepted as reference values, and the colors obtained in the dyeing were calculated according to the reference value. The measured $\mathrm{L}, \mathrm{a}, \mathrm{b}$ values are calculated as $\mathrm{L}-\mathrm{Lx}, \mathrm{a}-\mathrm{ax}, \mathrm{b}-\mathrm{bx}$, and the square root $\mathrm{dE}$ value of the sum of squares is calculated. If the color values reached in this formula are low, the result is that the distance with white reference value is low and if it is high, the distance with this value is too much. The symbols and formulas used in colorimetry with colorimeter are shown below.

L: Brightness coordinates of the undyed sample

Lx: Brightness coordinates of the dyed sample

Lmax:100 white

Lmin:10 black

a: The red-green coordinate of the undyed sample

ax: The red-green coordinate of the dyed sample

+392: Dark red

-392: Dark green

b: Blue-yellow coordinate of undyed sample

bx: Blue-yellow coordinate of dyed sample

+157: Dark yellow

-157: Dark blue

$$
\mathrm{dE}: \quad \sqrt{(L-L x)^{2}+(a-a x)^{2}+(b-b x)^{2}}
$$

\subsubsection{Determination of Light and Rubbing Fastness of Obtained Colors}

The light fastness of the colors obtained from the dyed materials (wool yarn, cotton fabric and paper) was determined according to TS EN ISO 105-B01. The dyed materials was exposure light together with the standard blue wool sample. The fading levels in the colour were determined by the blue scale. Blue wool scales are wool fabrics in striped grades from 1 to 8 grades. In the scale, 1 represents light blue color and 8 the darkest blue color.

Rubbing fastness tests were performed according to TS EN ISO 105-X12 with a rubbing fastness tester. The dyed materials were placed on the floor of the test device. In the corresponding part where the rubbing is to be formed, a white colored plain weaved cotton cloth with a size of $5 \times 5$ $\mathrm{cm}$ was placed. A $10 \mathrm{~cm}$ of the dyed sample was rubbed back and forth 10 times on a plain line at every 10 seconds with a 900 gram of load. The uncolored cotton with color flow was evaluated by gray-white scale and the rubbing fastnesses were determined.

\subsubsection{Statistical Evaluation of Research Data}

The result of the research were evaluated statistically using SPSS programme with nonparametric tests (Kruskal- Wallis $\mathrm{H}$ and Mann- Whitney U). Since the number of data is less than 30 , nonparametric tests were preferred for data analysis. In these tests, the levels of the groups are used to test whether the groups are different from each other. The Kruskal-Wallis $\mathrm{H}$ test was used to compare $\mathrm{k}$ groups, and the Mann-Whitney $\mathrm{U}$ test was used in binary comparisons. $\mathrm{p}$ value obtained as a result of the test; $\mathrm{p} \leq 0.05$ was interpreted as a statistically significant difference between the groups.

\section{Research Findings}

\subsection{Colors obtained from Dyeing Yarn, Fabric and Paper and Colorimeter Evaluation}

In the study, various colors were obtained as a result of dyeing of different materials. The names of these colors and the $\mathrm{dE}$ values obtained from the measurements with the colorimeter are given in table 1 below.

Table 1. Colors obtained from madder, walnut, weld and weld-indigo in natural dyeing of different materials and dE values of these colours.

\begin{tabular}{|c|c|c|c|c|c|}
\hline $\mathrm{Nr}$ & Plant and Plant Ratio & Material Type & Color Name & dE Value & Dyed Sample \\
\hline 1 & & Wool Yarn & Tile Red & 29.85 & 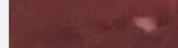 \\
\hline 2 & & Cotton Fabric & Peach Red & 28.71 & \\
\hline
\end{tabular}




\begin{tabular}{|c|c|c|c|c|c|}
\hline $\mathrm{Nr}$ & Plant and Plant Ratio & Material Type & Color Name & dE Value & Dyed Sample \\
\hline 3 & & Paper & Salmon & 38.57 & \\
\hline 4 & & Wool Yarn & Light Wood Roast Coffee & 9.43 & \\
\hline 5 & $\begin{array}{l}\text { Walnut } \\
1: 1\end{array}$ & Cotton Fabric & Beije & 8.59 & \\
\hline 6 & & Paper & Light Cinnamon & 31.70 & \\
\hline 7 & & Wool Yarn & $\begin{array}{l}\text { Light Infiltrated Olive } \\
\text { Oil }\end{array}$ & 17.624 & \\
\hline 8 & Weld, 1:1 & Cotton Fabric & Haw Yellow & 16.64 & \\
\hline 9 & & Paper & Light Lemon & 48.04 & \\
\hline 10 & & Wool Yarn & Off-Turquoise & 21.23 & \\
\hline 11 & Indigo & Cotton Fabric & Aqua & 38.97 & \\
\hline 12 & & Paper & Light Aqua & 16.53 & \\
\hline 13 & Weld + Indigo & Wool Yarn & Pistachio Green & 20.86 & b \\
\hline
\end{tabular}




\begin{tabular}{|c|c|c|c|c|c|}
\hline $\mathrm{Nr}$ & Plant and Plant Ratio & Material Type & Color Name & dE Value & Dyed Sample \\
\hline 14 & & Cotton Fabric & Nile Green & 18.17 & \\
\hline 15 & & Paper & Serene Green & 19.01 & \\
\hline
\end{tabular}

When Table 1 is examined, it is seen that tile red with dyeing of wool yarn with madder, peach reddish from dyeing of cotton fabric, salmon with dyeing of paper; light wood roasted coffee with dyeing of wool yarn with walnut, beige from dyeing of cotton fabric, light cinnamon from dyeing of paper; light Infiltrated olive oil from dyeing wool yarn with weld, haw yellow from dyeing of cotton fabric, light lemon from dyeing of paper; off-turquoise with dyeing of wool yarn with indigo, aqua color from dyeing of cotton fabric, light aqua from dyeing of paper, pistachio green from dyeing of wool yarn with weld-indigo, nile green from dyeing of cotton fabric and serene green from dyeing of paper.

In the study, when the measurements carried out via the colorimeter were evaluated, it was found that the $\mathrm{dE}$ values of the colors varied between 8.59 and 48.04 ; the highest $\mathrm{dE}$ value on materials dyed with madder appears on paper while the lowest $\mathrm{dE}$ value is seen on cotton fabric. The highest $\mathrm{dE}$ value on materials dyed with walnut appears on paper while the lowest $\mathrm{dE}$ value shows up on cotton fabric. The highest $\mathrm{dE}$ value on materials dyed with weld appears on paper while the lowest $\mathrm{dE}$ value shows up on cotton fabric. The highest $\mathrm{dE}$ value on materials dyed with indigo appears on cotton fabric and the lowest $\mathrm{dE}$ value is observed on wool yarn. Finally, the highest $\mathrm{dE}$ value on materials dyed with weld+indigo emerges on wool yarn while the lowest $\mathrm{dE}$ value can be seen on cotton fabric. When $\mathrm{dE}$ values were evaluated statistically on a plant basis one by one, it was concluded that the effect of material type change on the value of $\mathrm{dE}$ for all plants was significant (Kruskal-Wallis H Test/ walnut, p:0.007, weld p:0.008, madder p:0.002, indigo p:0.009, weld+indigo:0.015).

In the pairwise comparisons made, the difference between the paper material and the other materials was found to be statistically significant for materials dyed with walnut and weld. The difference among each three material type was found to be statistically significant for materials dyed with madder and indigo. Finally the difference between yarn material and other materials for the ones dyed with weld+indigo was also found to be statistically significant (Mann Whitney U Test/ walnut, weld yarn and paper p:0.009, fabric and paper p:0.009/ madder, indigo- yarn and fabric p:0.009, yarn and paper p:0.009, fabric and paper $\mathrm{p}: 0.009 /$ weld+indigo - yarn and fabric p:0.016, yarn and paper p:0.016).

\subsection{Fastness Values of Dyed Materials}

The rubbing and light fastness of colors obtained as a result of dyeing of different materials in the study are given in Table 2.

Table 2. The fastness values of the colors obtained in the study.

\begin{tabular}{|c|c|c|c|c|}
\hline $\mathbf{N r}$ & $\begin{array}{l}\text { Plant/Plant } \\
\text { Ratio }\end{array}$ & Material Type & $\begin{array}{l}\text { Rubbing } \\
\text { Fastness }\end{array}$ & $\begin{array}{l}\text { Light } \\
\text { Fastness }\end{array}$ \\
\hline 1 & \multirow{3}{*}{ Madder/ 1:1 } & Wool Yarn & 2 & 4 \\
\hline 2 & & Cotton Fabric & 4 & 3 \\
\hline 3 & & Paper & $4 / 5$ & 3 \\
\hline 4 & \multirow{3}{*}{ Walnut/ 1:1 } & Wool Yarn & $3 / 4$ & 5 \\
\hline 5 & & Cotton Fabric & 4 & 4 \\
\hline 6 & & Paper & $4 / 5$ & 2 \\
\hline 7 & \multirow{3}{*}{ Weld / 1:1 } & Wool Yarn & $3 / 4$ & 6 \\
\hline 8 & & Cotton Fabric & $4 / 5$ & 6 \\
\hline 9 & & Paper & 5 & 4 \\
\hline 10 & \multirow{3}{*}{ Indigo } & Wool Yarn & $1 / 2$ & 2 \\
\hline 11 & & Cotton Fabric & $2 / 3$ & 5 \\
\hline 12 & & Paper & $3 / 4$ & 3 \\
\hline 13 & \multirow{3}{*}{ Weld + Indigo } & Wool Yarn & 3 & 4 \\
\hline 14 & & Cotton Fabric & $4 / 5$ & 4 \\
\hline 15 & & Paper & 4 & 3 \\
\hline
\end{tabular}

When rubbing fastness values in table 2 is analyzed, it is seen that the value varies between $1 / 2$ and 5 . The highest rubbing fastness is seen on paper amongst the materials dyed with madder, walnut, weld and indigo while the lowest rubbing fastness value can be seen on wool yarn. The highest rubbing fastness value is seen on cotton fabric among the materials dyed with weld+indigo and the lowest on wool yarn. On the other hand, when light fastness are evaluated, the values seem to vary between 2 and 6 . The highest light fastness is observed on wool yarn among the materials dyed with madder and walnut. The highest light fastness is seen on wool yarn and cotton fabric among the materials dyed with weld and weld+indigo while the highest light fastness appears on cotton fabric among the materials dyed with indigo. When the plants used in the research are compared, weld has the best values on all three materials in terms of rubbing and light fastness. It can also be said that the wool yarn dyed with indigo has the lowest values of rubbing and light fastness values.

When the light and rubbing fastnesses of the dyed materials were evaluated statistically, it was found that the effect of the material type change on the light fastness was not significant (Kruskal-Wallis H Test / p: 0.127) and the effect on the rubbing fastness was significant (Kruskal-Wallis H Test / $\mathrm{p}$ : 0.027). It was found that the difference between the yarn 
material and the other materials was statistically significant (Mann Whitney U Test / yarn and fabric p: 0.045, yarn and paper p: 0.015) among all the materials dyed in the pairwise comparisons for rubbing fastnesses. In this case, it can be inferred that this is because that the yarn content is protein based while other materials are cellulosic based.

\section{Conclusion}

Natural dyeing is a preferred practice as a traditional method of coloring various materials and to release the dyes obtained from various plants or animals that grow in nature. In this research, dyeing experiments were carried out using natural dyes on three different materials such as yarn, fabric and paper. As a result of the research, it was seen that red and red tones were obtained from materials dyed with madder, soil color from materials dyed with walnut, yellow and yellow tones from materials dyed with weld, blue and blue tones from materials dyed with indigo and finally green and green tones from materials dyed with weld-indigo. It can be said in the scope of the study that even if material is differed, the same colors can still be obtained with changes in tones from madder, walnut, weld, indigo and weld-indigo in naturel dyeing. These color varieties is observed to show consistency even in literature.

In the study, it was observed in dyeing experiments conducted that weld, from which light color tones are obtained, had the best values in terms of light and rubbing fastnesses.

This research, which presents a comparative example in dyeing different-sourced materials with plants, will be a source of more detailed and different studies to be carried out in this regard.

\section{Acknowledgements}

The authors thank to Eyüp Özcan for his contributions in dyeing of paper material.

\section{References}

[1] Genç, M. (2017). Sakarya Çevresi Doğal Boyarmadde Kaynakları ve Boyahaneler. Süleyman Demirel Üniversitesi Sosyal Bilimler Dergisi, Say1: 26, s. 100-119.

[2] Canikli, N. (1989). Kökboya (Rubia Tinctorum L.)' dan elde edilen renkler ve bu renklerin yün halı iplikleri üzerindeki 1şık ve sürtünme haslıkları, Yüksek lisans tezi (basılmamış), Ankara Üniversitesi, 60 s., Ankara.

[3] Brunello, F. (1973). The Art of Dyeing in the History of Mankind. 460s., Vicenza.

[4] Harmancığlu, M. (1955). Türkiye'de Bulunan Önemli Bitki Boyalarından Elde Olunan Renklerin Çeşitli Müessirlere Karşı Yün Üzerinde Haslık Dereceleri, Ankara Üniversitesi Basımevi, 211 s., Ankara.

[5] Baytop, T. (1997). Türkçe Bitki Adları Sözlüğü. Türk Dil Kurumu Yayınları: 578, 512 s., Ankara.

[6] Eyüboğlu, Ü., Okaygün, İ. ve Yaraş, F. (1983). Doğal Boyalarla Yün Boyama. Özkur Basımevi, 137s., İstanbul.

[7] Kayabaşı, N. (1996). Halı ve kilim ipliklerinin ceviz (Juglans Regia) meyve kabuğu ve yaprakları ile boyanmasından elde edilen renkler ve bu renklerin bazı haslık değerleri. Uluslararası Tekstil Konferans1 ve Sergisi, s.475-480, Bursa.

[8] Adrasko, R. J. (1971). Naturel Dyes and Home Dying. Dover Publications, 154 s., New York.

[9] Enez, N. (1987). Doğal Boyamacılık Anadolu'da Yün Boyamacılığında Kullanılmış Olan Bitkiler ve Doğal Boyalarla Yün Boyamacilığı, Marmara Üniversitesi Güzel Sanatlar Fakültesi, 449; 80s., İstanbul.

[10] Öztürk, İ. (1999). Doğal Bitkisel Boyalarla Yün Boyama, Dokuz Eylül Üniversitesi Yayınları, 102 s., İzmir.

[11] Parlak, T. (2007). Çoruh Vadisinde Bitkisel Boya Potansiyeli, 159 s, Ankara.

[12] Anonim (1991). Bitkilerden Elde Edilen Boyalarla Yün Liflerinin Boyanması. T. C. Sanayi ve Ticaret Bakanlığı Küçük Sanatlar Sanayi Bölgeleri ve Siteleri Genel Müdürlügü Yayınları, 167 s., Ankara.

[13] Giacomini F., Menegazzo M. A. B., Santos J. C. O., Arroyo P. A. and Barros M. A. S. D. (2017). Ecofriendly Dyeing of Silk with Extract of Yerba Mate. Textile Research Journal, Vol. 87(7), 829-837.

[14] Li Y. V., Malensek N., Sarkar A. K. and Xiang C. (2016). Colorfastness Properties of Persimmon Dye on Cotton and Wool Fabric. Clothing and Textile Research Journal, Vol. 34 (3), 223-234.

[15] Nateri A. S., Hajipour A., Dehnavi E. and Ekrami E. (2014). Colorimetric Study on Polyamides Dyeing with Weld and Pomegranate Peel Natural Dyes. Clothing and Textile Research Journal, Vol 32 (2), 124-135. 